\title{
Hekhalot Literature in Context
}

\section{Between Byzantium and Babylonia Ed. by Ra'anan Boustan, Martha Himmelfarb and Peter Schäfer}

[Hekhalot Literatur im Kontext. Zwischen Byzanz und Babylon.]

Veröffentlicht auf Englisch.

Die Erforschung der frühen jüdischen Mystik (Merkavah-Mystik) hat in den letzten 30 Jahren gewaltige Fortschritte gemacht. Das alte Modell einer linearen Entwicklung, ausgehend von einem einmaligen und möglichst frühen Ursprung, wird zunehmend durch neue Einsichten in die spezifischen - und sich wandelnden - kulturellen Kontexte in Frage gestellt, in denen diese Mystik entstand und ihren literarischen Niederschlag fand. Das byzantinische Palästina und das sassanidische Babylonien kristallisieren sich als die beiden entscheidenden Brennpunkte der Merkavah-Mystik heraus. Im vorliegenden Band untersuchen internationale Wissenschaftler aus verschiedenen Disziplinen und demnach auch unterschiedlichen Perspektiven die literarische Entstehung, kulturelle Bedeutung, religiöse Funktion und Überlieferung der Hekhalot Literatur.

\section{Inhaltsübersicht}

Ra'anan Boustan: Introduction

I. The Formation of Hekhalot Literature: Linguistic, Literary, and Cultural Contexts

Noam Mizrahi: The Language of Hekhalot Literature: Preliminary Observations - Peter Schäfer: Metatron in Babylonia Michael D. Swartz: Hekhalot and Piyyut: From Byzantium to Babylonia and Back - Alexei Sivertsev: The Emperor's Many Bodies: The Demise of Emperor Lupinus Revisited - Klaus Herrmann: Jewish Mysticism in Byzantium: The Transformation of Merkavah Mysticism in 3 Enoch - David M. Grossberg: Between 3 Enoch and Bavli Hagigah: Heresiology and Orthopraxy in the Ascent of Elisha ben Abuyah - Moulie Vidas: Hekhalot Literature, the Babylonian Academies and the tanna'im II. The Transmission and Reception of Hekhalot Literature: Toward the Middle Ages Peter Schäfer: The Hekhalot Genizah - Gideon Bohak: Observations on the Transmission of Hekhalot Literature in the Cairo Genizah - Ophir Münz-Manor: A Prolegomenon to the Study of Hekhalot Traditions in European Piyyut III. Early Jewish Mysticism in Comparative Perspective: Themes and Patterns Reimund Leicht: Major Trends in Rabbinic Cosmology - Rebecca Lesses: Women and Gender in the Hekhalot Literature Andrei A. Orlov: »What is Below?« Mysteries of Leviathan in the Early Jewish Accounts and Mishnah Hagigah 2:1 - Michael Meerson: Rites of Passage in Magic and Mysticism - Annette Yoshiko Reed: Rethinking (Jewish-)Christian Evidence for Jewish Mysticism

Ra'anan S. Boustan Born 1971; 2004 PhD from Princeton University; 2004-06 Assistant Professor of Early Judaism at the University of Minnesota; 2006-10 Assistant Professor of Ancient and Jewish History at the University of California, Los Angeles; 2010-17 Associate Professor of Ancient and Jewish History at the University of California, Los Angeles; 2009-12 Director at the Center for the Study of Religion; since 2017 Research Scholar in the Program for Judaic Studies at Princeton University.

Martha Himmelfarb Born 1952; PhD from the University of Pennsylvania; currently William H. Danforth Professor of Religion, Princeton University, Princeton.

Peter Schäfer Geboren 1943; 1968 Promotion; 1973 Habilitation; 1983-2008 Professor für Judaistik an der Freien Universität Berlin; 1998-2013 Ronald O. Perelman Professor of Jewish Studies und Professor of Religion an der Princeton University; 2014-2019 Direktor des Jüdischen Museums Berlin.

Jetzt bestellen:

https://mohrsiebeck.com/buch/hekhalot-literature-in-context-9783161525766?no_cache=1

order@mohrsiebeck.com

Telefon: +49 (0)7071-923-17

Telefax: $+49(0) 7071-51104$ 